\title{
The puzzling situation of hospital exemption for advanced therapy medicinal products in Europe and stakeholders' concerns
}

\author{
NATIVIDAD CUENDE ${ }^{1}$, CHRISTELLE BONIFACE $^{2}$, CHRISTOPHER BRAVERY $^{3}$, \\ MIGUEL FORTE ${ }^{2}$, ROSARIA GIORDANO ${ }^{4}$, MARTIN HILDEBRANDT $^{5}$, ANDER IZETA ${ }^{6}$ \\ \& MASSIMO DOMINICI ${ }^{7}$, ON BEHALF OF THE LEGAL AND REGULATORY AFFAIRS \\ COMMITTEE-EUROPE, INTERNATIONAL SOCIETY FOR CELLULAR THERAPY \\ ${ }^{1}$ Andalusian Initiative for Advanced Therapies, Servicio Andaluz de Salud, Funta de Andalucia, Sevilla, Spain, \\ ${ }^{2}$ TxCell SA, Valbonne, Sophia Antipolis, France, ${ }^{3}$ Consulting on Advanced Biologicals Ltd. London, United Kingdom, \\ ${ }^{4}$ Cell Factory, Fondazione IRCCS Ca' Granda Ospedale Maggiore Policlinico, Milan, Italy, ${ }^{5}$ TUMCells \\ Interdisciplinary Center for Cellular Therapies, Technische Universität München, instead of. Munich, Germany, ${ }^{6}$ Tissue \\ Engineering Laboratory, Instituto Biodonostia, Hospital Universitario Donostia, San Sebastian, Spain, ${ }^{7}$ Laboratory of \\ Cell Biology and Advanced Cancer Therapies, University Hospital of Modena and Reggio Emilia, Modena, Italy
}

\section{Background}

In Europe, advanced therapy medicinal products (ATMPs), including cell and gene medicinal products [1], tissue-engineered products [2] and combined ATMPs [2], are governed by Directive 2001/ 83/EC [3] and Regulation 726/2004 [4], amended by Regulation 1394/2007 [2], which sets specific rules concerning their centralized marketing authorization (MA), supervision and pharmacovigilance.

Nevertheless, ATMPs not intended to be marketed and not industrially prepared are beyond the scope of Directive 2001/83/EC, according to article 28 of Regulation 1394/2007. This is commonly called "hospital exemption" (HE) and is restricted to any ATMP "which is prepared on a non-routine basis according to specific quality standards, and used within the same Member State in a hospital under the exclusive professional responsibility of a medical practitioner, in order to comply with an individual medical prescription for a custom-made product for an individual patient." Member States must ensure that the manufacture of ATMPs under HE is authorized by the competent national authority and that traceability, pharmacovigilance and specific quality standards are equivalent to those applying to ATMPs granted centralized MA.

HE requires transposition into national laws. Some European countries have already done this, with Finland, United Kingdom and Germany being the first. The difficulties associated with the interpretation of HE has led them to setting sometimesdivergent pathways and rules [5].

\section{Primary issue arising within the scope of $\mathrm{HE}$}

Directive 2001/83/EC does not specify what is meant by "industrial process," nor does the regulation specify the meaning of a "custom-made product." Nevertheless, some countries have defined those terms. In the United Kingdom, the Human Tissue Authority [6] has defined "custom-made" as "using a one-off formulation or a formulation that has been tailored to the individual patient and prepared within the same hospital" and "An industrial process would generally take place in an external facility and not within the same hospital." This is a specific interpretation; the process (industrial or not) is the most important aspect, not the location, because the same process can take place in facilities inside or outside hospitals. In fact, HE clause (Regulation 1394/2007) is in effect irrespective of the type of manufacturer.

\section{Different interpretation of HE in European Countries}

Countries have interpreted the definition of "nonroutine basis" differently because the European

Correspondence: Natividad Cuende, MD, MPH, PhD, Andalusian Initiative for Advanced Therapies, Servicio Andaluz de Salud, C/ Maese Rodrigo, no. 1, $1^{\circ}$ Izq., 41001, Sevilla, Spain. E-mail: natividad.cuende.sspa@juntadeandalucia.es 
Commission has never specified any particular number to constitute "non-routine." The United Kingdom takes the view that "it is not feasible to provide a simple numerical formula that would delineate the boundary between routine and nonroutine production" [7]. The Netherlands has chosen a concrete definition of "non-routine basis," allowing the infusion of one product for a maximum of five patients and fewer than ten patients a year [8]. The German Medicinal Products Act [9] has defined ATMPs prepared on a non-routine basis as those "medicines which are manufactured in small quantities, and in the case of which, based on a routine manufacturing procedure, variations in the procedure which are medically justified for an individual patient, are carried out, or which have not yet been manufactured in sufficient quantities so that the necessary data to enable a comprehensive assessment are not yet available." In the case of Finland $[10,11]$ France [12], Spain [13] and Portugal [14], there are no provisions for any specific quantity.

Regarding the entity holding the license, most countries grant HE to ATMP manufacturers, and in Spain and Portugal the license is given to hospitals. In Spain the licence is irrespective of the manufacturer. Therefore, if several Spanish hospitals were interested in using an ATMP produced by a single manufacturer, each hospital should submit a dossier equivalent to a Common Technical Document.

Although most countries require Good Manufacturing Practice (GMP) as the quality standard applicable under the $\mathrm{HE}$ scheme, there are some differences. In the United Kingdom, a qualified person is not required [15]. In Germany, "person identity" of the manufacturer is not necessary. Although GMP is required in the Netherlands, France and Spain, there is some degree of flexibility.

\section{When does HE apply?}

Perhaps the most important issue regarding $\mathrm{HE}$ is the situation or circumstances in which it applies with marked differences among countries. In the United Kingdom, the HE scheme "does not apply to ATMPs that will be authorised under the ATMP Regulation ... nor does it apply to ATMPs supplied as investigational ATMPs for use in a clinical trial (CT) [15]." Nevertheless, the United Kingdom established a second scheme for unlicensed products by implementing a procedure to supply "specials" (ATMPs) under Article 5(1) of Directive 2001/83/ $\mathrm{EC}$ that, in contrast to $\mathrm{HE}$, allows import and export of unlicensed ATMPs. The Netherlands applies HE for patients ineligible for a CT (as in compassionate use) or when the required product falls outside the specifications. In Finland, quality (but not nonclinical) data are required, allowing small-scale clinical use while non-clinical studies are carried out to facilitate a later CT. However, in Spain it is only possible to apply for HE when efficacy and safety have been demonstrated, and quality, non-clinical and clinical data must be provided. Here $\mathrm{HE}$ is considered as an alternative to MA for products non-industrially manufactured and not intended to be marketed, but not as an alternative to CTs. In Germany $\mathrm{HE}$ may be applicable to facilitate or accompany a CT (not as an alternative) but also for conveying products in a preliminary "non-routine status" on their way to centralized MA. In France, ATMP under HE require same clinical trials than other medicinal products and in Portugal there are no provisions regarding when $\mathrm{HE}$ applies.

On the subject of the duration of the authorization under HE, in Netherlands the product-specific license lasts for 10 batches or for 1 year, whereas in Germany there is no precise product-specific license period. In the case of Finland, the license for nonindustrial manufacture of ATMPs may be granted for a fixed or indefinite term, in Portugal is granted by one year being renewable and in Spain authorization is initially granted for 3 years and then for 5 years in successive renewals.

\section{The concerns of the affected stakeholders}

Small and medium enterprises and non-for-profit organizations (mainly universities and public hospitals) are leading the clinical development of ATMPs in Europe, with great variability among countries. In Spain and Italy the role of industry has been minimal, whereas in the United Kingdom, Germany, France, Sweden and Denmark, it has been quite important [16]. These differences have probably been instrumental in the way National Authorities have implemented HE. Here there are several examples. Germany has been the leading country in granting products under HE, most of them in the German market before the entry into force of the Regulation 1394/2007/EC. This has allowed those companies that have not applied for or have not been granted a European MA to continue their activity there. Although the United Kingdom was one of the first countries regulating $\mathrm{HE}$, the majority of the authorizations to manufacture and supply unlicensed ATMPs have been granted under the United Kingdom's "Specials" scheme. This scheme permits import and export activities, affording competitive advantage for the United Kingdom in comparison to other countries. Spain, with unlicensed ATMPs included in the Common Services Portfolio of the National Healthcare System as standard of care without 
locally marketed products, has recently regulated $\mathrm{HE}$ as an authorization for hospital use, but not as a national MA. This might maintain the provision of those treatments in hospitals.

Because of these differences between countries, members from both industry and academia are demanding harmonization in HE rules [17]. In the case of industry, regulatory predictability is important in making large investments, as is market size and market access unhindered by unfair competition [18]. However, HE was provided to allow some flexibility and to enable Member States to fit their individual circumstances to ATMP Regulation, as we have seen.

The recent report on ATMPs Regulation published by the European Commission [19] states: "It is necessary to find a balance between the need to ensure that ATMPs are made available to patients only after the quality, efficacy and safety thereof has been adequately demonstrated, and the need to facilitate early access for new treatments in case of unmet medical needs."

In this sense, some developers are concerned about the availability of ATMPs that were part of established clinical practice before the introduction of ATMP regulation as well as upcoming products with documented clinical efficacy that are currently not candidates for MA because of insufficient preclinical data. For these products, the current HE may be too restrictive in some cases.

There are also other situations that do not fit perfectly into the current regulation, especially for those products with little commercial interest but that are addressing unmet clinical needs. Where products lack intellectual property (especially minimally manipulated autologous products derived from processing technologies broadly used in most hospitals for other similar products not considered as ATMPs, i.e., bone marrow cells) [20], it could be useful to facilitate their introduction into practice irrespective of the number of patients treated once their quality is guaranteed and safety and efficacy have been demonstrated in randomized clinical trials [21]. For other products in which low disease prevalence discourages enterprises because of the small potential market, and orphan designation may not be suitable, HE should allow import and export activities.

The latter situations mainly concern institutions with a primary focus in generating knowledge and enabling patient access to safe and efficacious non-industrially manufactured ATMPs with reduced interest in marketing those products. The modification of the regulation and potential broadening of the $\mathrm{HE}$ limits specifically in products with reduced commercial potential while supporting the granting of MA for industrially prepared products intended to be marketed could thus benefit all stakeholders, allowing European public health care systems and academic GMPs to complement rather than compete with small and medium enterprises.

\section{References}

[1] Commission Directive 2009/120/EC of 14 September 2009 amending Directive 2001/83/EC of the European Parliament and of the Council on the Community code relating to medicinal products for human use as regards advanced therapy medicinal products. Off J Eur Union 2009 (September 15);L 243:3-12.

[2] Regulation (EC) No 1394/2007 of the European Parliament and of the Council of 13 November 2007 on advanced therapy medicinal products and amending Directive 2001/83/ EC and Regulation (EC) No 726/2004. Off J Eur Union 2007(October 12);L 324:121-37.

[3] Directive 2001/83/EC of the European Parliament and of the Council of 6 November 2001 on the Community code relating to medicinal products for human use. Off $\mathrm{J}$ Eur Commun 2001(November 28);L 311:67-128.

[4] Regulation (EC) No 726/2004 of the European Parliament and of the Council of 31 March 2004 laying down Community procedures for the authorisation and supervision of medicinal products for human and veterinary use and establishing a European Medicines Agency. Off J Eur Union 2004(April 30);L 136:1-33.

[5] Hospital exemption for ATMPs (implementation of Art 28(2) of Regulation 1394/2007): update on feedback received by the Commission. Pharmaceutical Committee. 22 October 2012. PHARM 608, <http://ec.europa.eu/health/files/advtherapies/ 2013_05_pc_atmp/07_2_pc_atmp_2013.pdf> [accessed 11 . 08.2014].

[6] ATMP definitions. Human Tissue Authority, <http://www. hta.gov.ul/_db/_documents/ATMP_definitions_200901191224. pdf $>$ [accessed 11.08.2014].

[7] Guidance on "non routine." Medicines and Healthcare products Regulatory Agency (MHRA), <http://www.mhra. gov.ul/home/groups/es-policy/documents/publication/con051880. pdf $>$ [accessed 11.08.2014].

[8] Procedure voor het verkrijgen van een hospital exemption voor ATMPs (versieapril 2011). Inspectievoor de Gezondheidszorg (not available in English), <http://www.igz.nl/ Images/Procedure $\% 20$ ATMP $\% 20$ huisstijl $\% 20$ rev $\% 20$ april $\%$ 202011_tcm294-283446.pdf> [accessed 11.08.2014].

[9] Medicinal Products Act (the Drug Law) (ARZNEIMITTELGESETZ - AMG) of the Federal Republic of Germany (nonofficial translation), <http:/www.pei.de/SharedDocs/Downloads/EN/ 111013-amg-en.pdf?_blob $=$ publicationFile $\& v=2>$ [accessed 11 . 08.2014].

[10] Medicines Act 395/1987 Unofficial translation; Amendments up to 1340/2010 included. FIMEA, < http://www.fimea.fi/download/ 18580_Laakelaki_englanniksi_paivitetty_5_2011.pdf> [accessed 11.08.2014].

[11] Administrative Regulation 3/2009. Pitkällekehitetyssäterapiassakäytettävienlääkkeidenvalmistaminenyksittäisenpotilaa nkäyttöön [not available in English]. FIMEA, <http://www. fimea.fi/instancedata/prime_product_julkaisu/fimea/embeds/fi meawwwstructure/17048_Pitkalle_kehitetyssa_terapiassa_maa rays_3_2009.pdf $>$ [accessed 11.08.2014].

[12] LOI n ${ }^{\circ}$ 2011-302 du 22 mars 2011 portant diverses dispositions d'adaptation de la législation au droit de l'Union européenne en matière de santé, de travail et de communications électroniques [not available in English], <http://www.legifrance.gouv. fr/jopdf/common/jo_pdf.jsp?numJO=0\&date $\mathrm{O} O=20110323 \&$ numTexte $=6 \&$ pageDebut $=05186 \&$ pageFin $=05193>$ [accessed 11.08.2014]. 
[13] Real Decreto 477/2014, de 13 de junio, por el que se regula la autorización de medicamentos de terapia avanzada de fabricación no industrial [not available in English], <https:// www.boe.es/boe/dias/2014/06/14/pdfs/BOE-A-2014-6277. pdf $>$ [accessed 11.08.2014].

[14] Portaria n. ${ }^{\circ} 138 / 2014$ de 7 de julho. Diário da República, $1{ }^{a}$ série, N. ${ }^{\circ} 128,7$ de julho de 2014 (not available in English). http://dre.pt/pdf1s/2014/07/12800/0369603702.pdf [accessed 01.09.2014].

[15] Guidance on the UK's arrangements under the hospital exemption scheme. Medicines and Healthcare products Regulatory Agency (MHRA), <http://www.mhra.gov.ul home/groups/es-policy/documents/publication/con 065623. pdf $>$ [accessed 11.08.2014].

[16] Maciulaitis R, D'Apote L, Buchanan A, Pioppo L, Schneider CK. Clinical development of advanced therapy medicinal products in Europe: evidence that regulators must be proactive. Mol Ther 2012;20:479-82.

[17] Erben RG, Silva-Lima B, Reischl I, Steinhoff G, Tiedemann G, Dalemans W, et al. White paper on how to go forward with cell-based advanced therapies in Europe [published online ahead of print June 3, 2014]. Tissue Eng Part A.

[18] Alliance for Advanced Therapies. Focus hospital exemption on developing innovative and safe treatments for patients. Regen Med 2013;8:121-3.

[19] Report from the Commission to the European Parliament and the Council in accordance with article 25 of regulation (EC) no 1394/2007 of the European Parliament and of the Council on Advanced Therapy Medicinal Products and amending Directive 2001/83/EC and Regulation (EC) no 726/2004. Com(2014) 188 final, <http://eur-lex.europa.eu/legalcontent/ES/TXT/PDF/?uri=COM:2014:188:FIN\&rid=12> [accessed 11.08.2014].

[20] Cuende N, Rico L, Herrera C. Bone marrow mononuclear cells for the treatment of ischemic syndromes: medicinal product or cell transplantation? Stem Cells Transl Med 2012; 1:403-8.

[21] Cuende N, Herrera C, Keating A. When the best is the enemy of the good: the case of bone-marrow mononuclear cells to treat ischemic syndromes. Haematologica 2013;98:323-4. 